CARADDE: Jurnal Pengabdian Kepada Masyarakat
institute
$\begin{gathered}\text { https://journal.ilininstitute.com/index.php/caradde } \\ \text { Volume 1 | Nomor 2 | Februari | 2019 } \\ \text { e-ISSN: } 2621-7910 \text { dan p-ISSN: 2621-7961 }\end{gathered}$

\title{
Peningkatan Pengetahuan dan Keterampilan Orang Tua Untuk Mencegah Bullying Guna Mewujudkan Desa Layak Anak
}

\section{Purwati $^{1}$, Muhammad Japar ${ }^{2}$, Septi Wardani ${ }^{3}$ Rohmayanti $^{4}$}

\begin{tabular}{|c|c|}
\hline Keywords & Abstrak. Bullying merupakan bentuk perilaku agresifyang sering \\
\hline Pengetahuan & dilakukan anak atau individu secara sengaja dan berulang-ulang \\
\hline Keterampilan Orang Tua & untuk menyakiti anak atau individu lain demi mendapatkan \\
\hline Bullying & kepuasan dan kebahagiaan. Orang tua berperan sangat penting \\
\hline Desa layak anak & $\begin{array}{l}\text { untuk membentuknya dan selanjutnya mampu mencegah } \\
\text { timbulnya perilaku yang tidak baik seperti bullying. Tujuan dar }\end{array}$ \\
\hline Corespondensi Author & pengabdian ini adalah untuk meningkatkan pengetahuan dan \\
\hline Fakutas Keguruan dan Ilmu & keterampilan orang tua dalam mencegah bullying, dem \\
\hline Pendidikan/ Universitas & mewujudkan desa layak anak. Metode yang digunakan adalah \\
\hline Muhammadiyah Magelang, & Rural Apraissal, dengan pendekatan dalam proses pemberdayaan \\
\hline J1. Tidar No 21 Magelang 56126 & dan peningkatan partisipasi masyarakat, yang tekanannya pado \\
\hline bupurwati@ummgl.ac.id/ & keterlibatan masyarakat dalam keseluruhan kegiatan. Hasil yang \\
\hline bupurwati@gmail.com & $\begin{array}{l}\text { didapatkan dari kegiatan pengabdian ini yaitu terjadinya } \\
\text { peningkatan pengetahuan pada orang tua sebanyak } 23\end{array}$ \\
\hline History Artikel & Kesimpulan, meningkanya pengetahuan dan keterampilan orang \\
\hline $\begin{array}{l}\text { Received: November-2018; } \\
\text { Reviewed: Desember- } 2018\end{array}$ & $\begin{array}{l}\text { tua dapat mencegah bullying pada anak, sehingga akan } \\
\text { mendukung terwujudnya desa layak anak. }\end{array}$ \\
\hline
\end{tabular}

Accepted: Februari-2019

Published: Februari-2019

This work is licensed under a Creative Commons Attribution

4.0 International License

\section{PENDAHULUAN}

Desa layak anak (DLA) adalah suatu pembangunan desa dengan menyatukan sumber daya dan komitmen pemerintah desa yang melibatkan warga dan badan usaha yang berada di desa, untuk mempromosikan, melindungi, memenuhi dan menghormati hak-hak anak (Menteri, 2011). Desa layak anak sangat penting diwujudkan untuk mendukung perlindungan dan tumbuh kembang anak serta mewujudkan tempat tinggal anak atau desa sebagai media bibit sumber daya manusia yang unggul dan berkualitas(Rumtianing, 2014). Tujuan dari DLA untuk meningkatkan kepedulian dan upaya konkrit desa dalam upaya mewujudkan pembangunan desa yang menjamin pemenuhan hak-hak anak, memastikan pembangunan desa dengan memperhatikan kebutuhan anak, aspirasi dan kepentingan terbaik bagi anak(Subiyakto, 2012). Pembangunan desa yang dilakukan juga tidak memberikan diskriminasi terhadap anak, termasuk anak bebas bullying. Selain itu juga menyatukan potensi dan realisasi Sumber Daya Manusia, sumberdaya alam, sumber dana, sarana, prasarana, metoda dan teknologi, serta partisipasi masyarakat yang ada pada pemerintahan desa. Salah satu indicator desa layak anak adalah klaster perlindungan khusus. Dikatakan sudah memenuhi klaster tersebut jika desa sudah mampu memberikan perlindungan terhadap 


\section{Caradde: Jurnal Pengabdian Kepada Masyarakat}

Vol 1 No 2, Februari 2019

anak, memberikan ruang atau lingkungan yang kondusif dalam perkembangan anak dan memenuhi hak-hak anak (Arifin, 2016). Dengan dapat dicegahnya bullying pada anak, diharapkan anak akan mendapatkan haknya untuk memperoleh standar kehidupan yang layak agar bisa berkembang secara optimal, baik fisik, mental, spiritual, moral maupun sosial dengan baik (Rumtianing, 2014).

Bullying merupakan bentuk perilaku agresif yang sering dilakukan anak atau individu secara sengaja dan berulang-ulang untuk menyakiti anak atau individu lain demi mendapatkan kepuasan dan kebahagiaan (Peter K Smith, 2016). Bullying dapat terjadi di mana saja yaitu di lingkungan masyarakat umum maupun lingkungan pendidikan (sekolah formal dan non-formal). Dua faktor besar yang mempengaruhi perilaku bullying pada anak, yaitu (1) faktor eksternal : lingkungan keluarga, sekolah dan masyarakat , dan (2) faktor internal individu (sifat, kepribadian, karakter). Perilaku bullying yang terjadi pada anak meliputi : 1) Penyerangan fisik: memukul, mendorong , menendang, mencubit dan seterusnya, 2) Penyerangan verbal: mengejek, menyebarkan isu buruk, atau menjuluki sebutan yang jelek, 3) Penyerangan emosi: menyembunyikan peralatan sekolah, memberikan ancaman, menghina, 4) Penyerangan Rasial: mengucilkan anak karena Ras, agama, kelompok, 5) Penyerangan seksual: meraba, mencium dan seterusnya(M. SandyHershcovis, Tara C.Reich, 2015). Keluarga merupakan lingkungan pertama dan utama yang menjadi tempat untuk menjadikan anak mempunyai karakter dan kepribadian yang baik sehingga mampu menyesuaikan diri dengan baik. Penyesuaian diri tersebut dapat dilakukan terhadap diri sendiri dan lingkungan (Krahe, 2005). Selain faktor internal dan ekternal yang mempengaruhi bullying, teknologi informasi juga dapat mempengaruhi perilaku bullying. Dampak negative tersebut adalah cyberbullying, yaitu perlakuan yang ditujukan untuk mempermalukan, menakut-nakuti, melukai, ataupun melakukan hal-hal yang merugikan orang lain (Rahayu, 2012).

Orang tua yang tidak mengajarkan atau memberikan contoh perilaku positif pada anak, maka akan beresiko membentuk anak yang mempunyai kecenderungan melakukan bulliying terhadap anak lain. Selain itu apabila orang tua tidak memberikan konsekuensi secara konsisten kepada anak ketika melakukan kesalahan ataupun melanggar peraturan, maka hal tersebut akan memperbesar kemungkinan anak beresiko menjadi pelaku bullying (Hidayati, 2012).

Bullying akan memberikan dampak yang merugikan bagi anak yang melakukan bullying, korban maupun masyarakat luas. Dampak tersebut dirasakan sebagai suatu trauma psikologis yang ringan sampai dengan berat bagi korban bullying. Dampak bagi pelaku bullying, akan merasakan stressor akibat perlakuan yang tidak baik dari keluarga atau teman sebayanya. Anak menjadi mudah tersinggung, tidak percaya diri dan tekanan secara psikologis. Pada korban bullying, dampak yang muncul bisa secara fisik maupun psikologis. Secara fisik anak bisa mengalami cedera fisik dari pelaku bullying dan trauma psikologis yang berlangsung lama. Dampak lain pada korban adalah depresi, merasakan luka yang mandalam, gangguan konsentrasi dan akhirnya anak akan mengalami penurunan belajar. Pada orang lain atau masyarakat juga akan merasakan trauma secara psikologis dari perlakuan yang diterima oleh korban (Hidayati, 2012). Bullying juga akan memberikan dampak depresi pada anak. Depresi akan memberikan dampak buruk pada anak, yaitu memicu munculnya perasaan cemas yang berlebihan, merasa ketakutan, bahkan beresiko memunculkan pikiran untuk melakukan bunuh diri (Tumon, 2014). Dari berbagai dampak yang muncul akibat bullying tersebut, maka pencegahan bullying pada anak menjadi hal yang sangat penting untuk dilakukan.

Desa Menayu merupakan salah satu desa di Kecamatan Muntilan yang sedang merintis segala bentuk implementasi untuk menuju desa layak anak. Dari survey yang sudah dilakukan oleh tim pengabdian, didapatkan permasalahan di Desa Menayu yang berkaitan dengan bullying. Dari hasil wawancara, masyarakat belum mengetahui mengenai bullying dan cara pencegahannya serta belum pernah mendapatkan informasi mengenai bullying. Orang tua dalam hal ini berperan sangat penting dalam mencegah timbulnya perilaku yang tidak baik seperti 
bullying. Untuk itu, pengabdian ini sangat penting dilakukan untuk meningkatkan pengetahuan dan keterampilan orang tua dalam mencegah bullying, sehingga diharapkan desa layak anak akan terwujud.

\section{METODE}

Metode yang digunakan dalam pengabdian ini adalah pemberdayaan masyarakat partisipatif dengan model Participatory Rural Apraissal yaitu suatu metode pendekatan dalam proses pemberdayaan dan peningkatan partisipasi masyarakat, yang tekanannya pada keterlibatan masyarakat dalam keseluruhan kegiatan yang dilaksanakan. Dalam pengabdian ini, mitra adalah pokja pkk di bebrapa dusun, yaitu dusun kepanjen, dusun sorogenen dan dusun jambean. Mitra tersebut mempunyai kompetensi standar, yaitu berpendidikan minimal setingkat smp, jumlah kader tiap pokja minimal 10 orang, telah memiliki pengalaman dalam pokja pkk selama lebih dari 5 tahun baik dibidang social, ekonomi, budaya, kesehatan maupun pendidikan. Tim yang melaksanakan pengabdian ini adalah tim dari Fakultas 1lmu Pendidikan dan Fakultas Ilmu Kesehatan, yang memiliki sara dan prasarana yang mendukung program pengabdian.

Dari Metode PRA yang digunakan dalam pengabdian ini ada 3 tahap. Tahap pertama yaitu Pengenalan masalah atau kebutuhan dan potensi serta penyadaran. Dalam tahap ini dilakukan identifikasi terhadap berbagai permasalahan yang dihadapi mitra pada semua indikator DLA. Metode untuk melakukan identifikasi adalah dengan observasi dan wawancara dengan pihak-pihak terkait yaitu kepala Desa Menayu, kelompok mitra yaitu bidan desa dan Pokja PKK, dan Dinas Kesehatan, Dinas Pendidikan. Tahap kedua adalah Perumusan masalah dan penetapan prioritas.

Hasil permasalahan yang sudah teridentifikasi selanjutnya didiskusikan melalui FGD dengan ketiga kelompok mitra (Pokja PKK Dusun Kepanjen, Dusun Sorogenen, Dusun Jambean) maupun BAPPEDA, DPPKAD, Bagian TAPEM, Camat, UPT KBKS, Kepala Desa, Bidan Desa untuk menentukan prioritas permasalahan yang akan diselesaikan selama 3 tahun dalam program PPDM ini.
Tahap ketiga adalah Identifikasi alternatif-alternatif pemecahan masalah atau pengembangan gagasan. Diskusi antara tim pengusul, mitra, dan BAPPEDA, DPPKAD, Bagian TAPEM, Camat, UPT KBKS, Kepala Desa, Bidan Desa. Pemerintah kecamatan Muntilan juga diterapkan pada penentuan alternatif-alternatif pemecahan masalah yang sudah diprioritaskan.

\section{HASIL DAN PEMBAHASAN}

Dari hasil observasi dan wawancara yang dilakukan dengan mitra, terdapat permasalahan yang teridentifikasi. Permasalahan tersebut yaitu, masyarakat khususnya orang tua tidak mengetahui mengenai bullying dan belum tahu bagaimana pencegahannya. Masyarakat juga belum pernah mendapatkan paparan informasi mengenai pencegahan bullying pada anak. Selain itu terdapat beberapa orang tua yang sering memarahi anak secara keras. Dari permasalahan tersebut didiskusikan dan ditentukan pemecahannya, yaitu salah satunya dilakukan pencegahan bullying dengan pemberian pelatihan untuk meningkatkan pengetahuan dan keterampilan pada orang tua. Di bawah ini adalah beberapa kegiatan pemberian pelatihan bullying kepada orang tua.

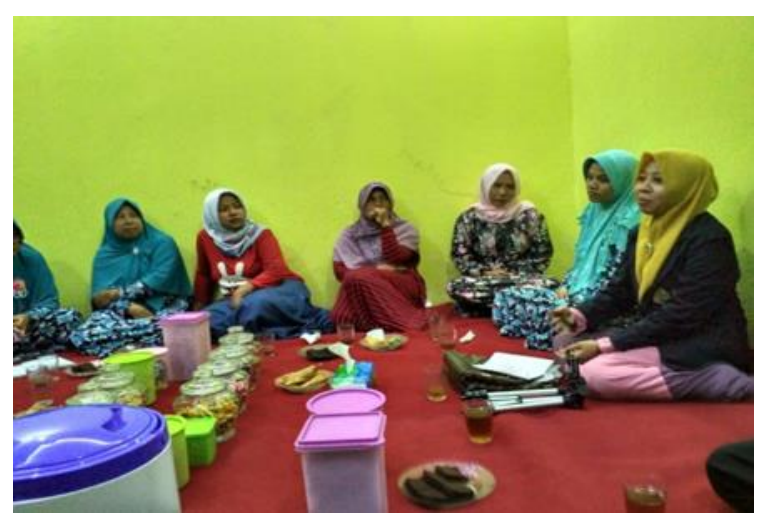

Gambar 1. Pemberian pelatihan pencegahan bullying 


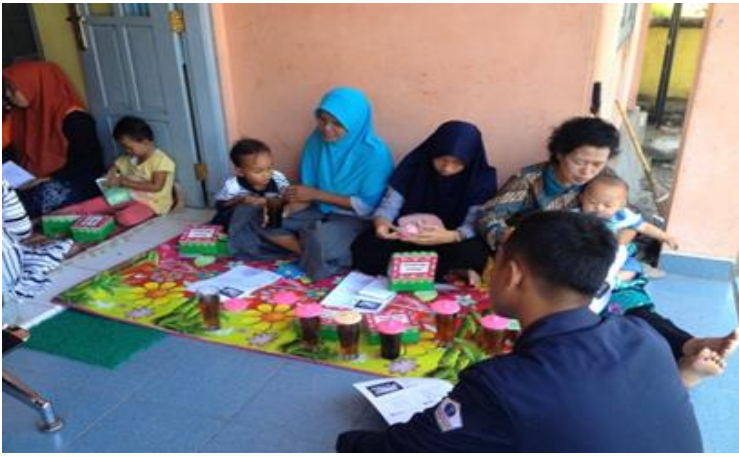

Gambar 3. Pendampingan orang tua dalam pencegahan bullying

Dari gambar di atas terlihat kegiatan penyuluhan yang diberikan kepada orang tua. Penyuluhan diikuti oleh 18 orang peserta, yang merupakan ibu-ibu di masyarakat desa menayu.

Pemberian penyuluhan tentang bullying dan pencegahannya sangat tepat diberikan kepada orang tua. Hal tersebut sesuai dengan Novianti (2008), yang menyampaikan bahwa salah satu penyebab terjadinya bullying pada anak adalah karena factor keluarga. Hal tersebut bisa terjadi karena anak tumbuh dalam keluarga yang agresif dan berlaku kasar, mendapatkan kekerasan baik fisik atau verbal dari orang tua, sehingga anak akan meniru kebiasaan tersebut dalam kesehariannya. Hal tersebut akan memicu anak untuk mencontohnya dan menjadi pelaku bullying terhadap temannya. Orang tua sebagai pendidik yang pertama dan utama harus mengetahui tentang bullying dan hal-hal apa saja yang dapat memicu terjadinya bullying, sehingga bullying dapat dicegah.

Tabel 1 tentng nilai pre tes dan post test menunjukan, bahwa dari 18 peserta yang mengikuti tes, terdapat 17 peserta mengalami kenaikan hasil dari pre dan post tes. Kenaikan hasil yang signifikan diperoleh oleh 2 peserta, yaitu peserta dengan kode $C$ sebanyak 45 kenaikan, dan pserta kode G dengan kenaikan sebanyak 35. Untuk 2 peserta tidak mengalami kenaikan nilai, karena nilai pre dan post tes hasilnya sama, sedangkan 2 peserta lagi tidak mengalami kenaikan karena hanya mengikuti post tes saja. Untuk rata-rata kenaikan nilai pre tes dan post tes dari seluruh peserta adalah sebesar 23 .
Di bawah ini akan disajikan tabel hasil Hasil yang didapatkan dari pre dan post tes pada kegiatan pengabdian ini disajikan pada table berikut ini.

Tabel 1. Nilai pre dan post test

\begin{tabular}{cccc}
\hline Kode pesera & $\begin{array}{c}\text { Nilai } \\
\text { pre test }\end{array}$ & $\begin{array}{c}\text { Nilai } \\
\text { post } \\
\text { test }\end{array}$ & $\begin{array}{c}\text { Hasil } \\
\text { kenaikan } \\
\text { test }\end{array}$ \\
\hline A & 80 & 80 & 0 \\
B & 50 & 80 & 30 \\
C & 40 & 85 & 45 \\
D & 40 & 70 & 30 \\
E & 50 & 75 & 25 \\
F & 60 & 60 & 0 \\
G & 35 & 70 & 35 \\
H & 50 & 65 & 15 \\
I & 60 & 75 & 15 \\
J & 45 & 75 & 30 \\
K & 50 & 70 & 20 \\
L & 50 & 75 & 25 \\
M & 55 & 80 & 25 \\
N & 30 & 70 & 40 \\
O & 70 & 90 & 20 \\
P & 60 & 90 & 30 \\
Q & 55 & 60 & 5 \\
R & 45 & 70 & 25 \\
\hline Rata-rata kenaikan & 23 \\
\hline
\end{tabular}

Dari hasil pengabdian menunjukan adanya peningkatan pengetahuan orang tua, sebelum diberikan transfer pengetahuan dan sesudah diberikan transfer pengetahuan. Hal tersebut menunjukan bahwa dengan pemberian penyuluhan, pengetahuan dan keterampilan orang tua tentang bullying meningkat. Selain itu, orang tua juga melakukan praktek secara langsung terhadap anaknya, dengan lebih melakukan control emosi terhadap anaknya. Dari praktek tersebut, dilakukan evaluasi setelah satu minggu dan didapatkan hasil melalui wawancara dan observasi, bahwa kekerasan secara verbal dari orang tua terhadap anak menurun.

Proses pembelajaran tentang bullying yang disampaikan dalam pemberian materi untuk meningkatkan pengetahuan orang tua dalam mencegah bullying cukup efektif. Hal tersebut dibuktikan dengan meningkatnya pengetahuan orang tua tentang bullying, 
aktifnya peran serta peserta, lebih komunikatif dan tidak terkesan formal. Hal itu sesuai dengan konsep participatory learning, bahwa belajar merupakan proses aktif, dimana peserta belajar tidak hanya dari pengajarnya, tetapi dari pengalaman mereka (Kaufman D,M., 2010). Hal tersebut dibuktikan, bahwa tidak hanya pengetahuan orang tua saja yang meningkat, tapi terjadi manajemen emosi yang lebih baik, yang akan menghindarkan anak mendapatkan kekerasan baik secara verbal maupun fisik.

Menurut (Notoatmojo, 2007), kurang lebih dari $75 \%$ pengetahuan manusia diperoleh melalui mata dan sisanya dari alat indera. Dalam kegiatan pelatihan ini menggunakan media power point, LCD dan leaflet. Penggunaan media yang sesuai akan memudahkan tercapainya tujuan dari pentransferan pengetahuan, sehingga memudahkan informasi untuk diterima peserta. Media yang digunakan dalam transfer pengetahuan tersebut disebut suatu media instruksi pembelajaran, yang artinya adalah semua sarana dimana stimulus dihadirkan bagi terwujudnya langkah pembelajaran. Langkah pembelajaran tersebut berupa materi, audio, visual atau audiovisual, suara pengajar serta peserta didik. Dengan media power point yang di dalamnya terdapat audio, visual, suara pengajar dan peserta akan memberikan rangsanganyang cukup baik sehingga informasi akan mudah diterima oleh peserta (Hariadi Samsul, 2017).

Dengan diberikannya pelatihan kepada orang tua tentang bullying, orang tua menjadi mengetahui apa saja factor yang menjadi penyebab bullying pada anak, sehingga orang tua akan berperan besar dalam mencegah bullying pada anak. Dengan tidak adanya bullying pada anak, berarti anak sudah mendapatkan haknya, yaitu mendapatkan perlakuan yang baik, tidak ada kekerasan secara fisik ataupun psikologis dan tidak ada diskriminasi. Anak juga tumbuh di lingkungan tempat tinggal dan sekolah yang kondusif, yang mendukung pemenuhan hakhak anak. Hal tersebut akan sangat mendukung terwujudnya desa yang layak terhadap anak.

\section{SIMPULAN DAN SARAN}

Pemberian pelatihan tentang bullying kepada orang tua, dapat meningkatkan pengetahuan tentang penyebab bullying, cara mengatasi dan mencegahnya. Hal tersebut ditandai dengan meningkatnya hasil pre dan post tes. Keterampilan orang tua juga meningkat, ditandai dari hasil wawancara dan observasi, kekerasan secara verbal dari orang tua menurun. Hal tersebut akan sangat mendukung terpenuhinya hak anak, sehingga desa yang layak terhadap anak akan terwujud. dengan bertambahnya

Dalam melaksanakan program-pragram untuk mewujudkan desa yang layak terhadap anak, khususnya mengenai pemenhan hakhak anak, sangat membutuhkan peran dan kontribusi dari berbagai pihak. Mitra merupakan pihak yang paling berkontribusi dalam mewujudkan tujuan DLA. Selain itu, pihak-pihak lainnya yang berperan adalah tim pengabdian sendiri, pemerintahan, lembaga dan badan usaha, sehingga program akan dapat terlaksana dengan baik dan desa mampu mewujudkan desa yang layak anak.

\section{DAFTAR RUJUKAN}

Arifin, S. (2016). Kota Layak Anak Berbasis Kesehatan. Berkala Kedokteran, Vol.12, No.1, Feb 2016: 117-122, 12(1), 117. Retrieved from https://media.neliti.com/media/publica tions/59304-ID-kota-layak-anakberbasis-kesehatan.pdf

Hariadi Samsul. (2017). Pengaruh Penggunaan Media Pembelajaran LCD Proyektor dan Motivasi Belajar Terhadap Prestasi Belajar Mata Pelajaran IPS. Jurnal Penelitian Dan Pendidikan IPS (JPPI) Volume 11 No 1 (2017) 100-110 ISSN (Print): 1858-4985, 11(1).

Hidayati, N. (2012). BullyingpadaAnak: AnalisisdanAlternatif Solusi. INSAN, 14(01), 41. Retrieved from http://www.journal.unair.ac.id/filerPD F/artikel 5-14-1.pdf

Kaufman D,M., M. K. . (2010). Teaching and Learning In Medical education: How theory can inform practice, dalam Understanding Medical education. London: WileyBlackwell. 
Krahe. (2005). Perilaku Agresif- Buku Panduan Psikologi Sosial. Yogjakarta: Pustaka pelajar.

M. SandyHershcovis, Tara C.Reich, and K. N. (2015). Workplace bullying: causes, consequences, and intervention strategies. Society for Industrial and Organizational Psychology, Inc. London. Retrieved from http://eprints.1se.ac.uk/66031/

Menteri, P. (2011). Peraturan menteri Perlindungan dan Pemberdayaan Perempuan dan Anak No. 11 Tahun 2011.

Notoatmojo. (2007). Promosi Kesehatan dan Ilmu Perilaku. Jakarta: Rineka Cipta.

Peter K Smith. (2016). Bullying: Definition, Types, Causes, Consequences andIntervention. Social and Personality Psychology Compass, 10(9), 519-532.

Rahayu, florencia sapty. (2012). Cyber Bullying Sebagai Dampak Negatif Penggunaan Teknologi Informasi. Journal of Information Systems, Volume 8 , Issue 1, April 2012, 8(1), 22. Retrieved from

http://jsi.cs.ui.ac.id/index.php/jsi/artic le/view/321/296
Rumtianing, I. (2014). Kota Layak Anak Dalam Perspektif Perlindungan Anak. Jurnal Pendidikan Pancasila Dan Kewarganegaraan, Th. 27, Nomor 1, Pebruari 2014, 27(1), 7.

Subiyakto, R. (2012). Membangun Kota LayakAnak:Studi Kebijakan Publik di Era Otonomi Daerah. SOSIORELIGIA,Vol. 10, No.1, Februari 2012, 10(1), 49. Retrieved from https://www.aifis-

digilib.org/uploads/1/3/4/6/13465004 /revisi_no_04._membangun_kota_rama h_anak_penulis_rudi_subiyakto.pdf

Tumon, M. B. A. (2014). Studi Deskriptif Perilaku Bullying pada Remaja. Calyptra: Jurnal Ilmiah Mahasiswa Universitas Surabaya, 3(1), 1. 